\title{
US nurse says she will fight Ebola quarantine
}

\author{
Michael McCarthy \\ Seattle
}

The US nurse who cared for patients with Ebola virus disease in west Africa and is now being held in quarantine in her home in Maine said on 29 October that she would challenge her detention in court.

The nurse, Kaci Hickox, was held in an isolation tent for three days outside a New Jersey hospital over the weekend after she returned from Sierra Leone. The 33 year old nurse was found to have a temperature of $101^{\circ} \mathrm{F}$ by a non-contact thermometer shortly after her arrival but was never found to be febrile when tested with oral thermometers. She had no symptoms of Ebola virus disease, and blood tests detected no evidence of infection with the virus.

Hickox was released on 27 October by the state of New Jersey and allowed to travel to her home in Maine. However, on her arrival in Maine officials ordered her to remain in quarantine in her home for 21 days after her last exposure to a patient with Ebola.

Hickox, who in numerous television and radio interviews given from her isolation tent lambasted New Jersey's governor, Chris Christie, for playing politics, has remained defiant, saying that her detention was without scientific justification and a violation of her constitutional rights.

"There are things that we know work, and all aid workers are willing to do those things, but I'm not willing to stand here and let my civil rights be violated when it's not science based," Hickox told reporters. Maine health officials said they intended to enforce the quarantine.

Governor Christie had defended his decision to quarantine Hickox. "Here's the bottom line as governor: my first responsibility is to protect the public health and safety of the people of New Jersey," Christie said in a television interview.

Under new guidelines issued on 27 October the US Centers for Disease Control and Prevention recommended that healthcare workers such as Hickox who were at "some risk" of infection undergo "direct active monitoring" for 21 days after their last potential exposure, the incubation period of Ebola infection. ${ }^{1}$
During this period public health officers visit the healthcare workers daily to check their temperature and to review their symptoms. Quarantine is not recommended for those in the "some risk" category, though public health officials may impose additional restrictions if the person had "intense" exposure, such as working with Ebola patients daily, the guidelines said.

Both federal and international health officials have voiced concern that onerous quarantine measures will discourage US healthcare workers from going to west Africa, where they are desperately needed. In a statement the charity Doctors Without Borders (Médecins Sans Frontières (MSF)) said that "blanket forced quarantine" for healthcare workers returning from Ebola affected countries was "not based upon established medical science."

The statement said, "Kaci Hickox has carried out important, lifesaving work for MSF in a number of countries in recent years, and we are proud to have her as a member of our organization. MSF respects Kaci's right as a private citizen to challenge excessive restrictions being placed upon her."

President Barack Obama, who opposes the states' quarantine policies, met at the White House on 29 October with healthcare workers who had recently returned from doing Ebola relief work in west Africa and called on Americans to honor those "who are putting themselves on the front lines of this fight."

Obama said, "They make huge sacrifices to protect this country that we love. And when they come home they deserve to be treated properly. They deserve to be treated like the heroes that they are."

\section{Access all of The BMSs content on the ongoing Ebola outbreak at thebmj.com/ebola.} McCarthy M. CDC rejects mandatory quarantine for travelers arriving from Ebola stricken
nations. BMJ 2014;349:96499.

Cite this as: BMJ 2014;349:96555

๑ BMJ Publishing Group Ltd 2014 